\title{
UMA VIAGEM RUMO AOS OUTROS CANTOS REZENDIANOS
}

\section{A JOURNEY TOWARDS REZENDE'S OUTROS CANTOS}

\author{
Isabela Rodrigues Lobo ${ }^{1}$ \\ ORCID: https://orcid.org/0000-0001-9796-8904
}

\begin{abstract}
Resumo: A partir de uma breve descrição de como se configurou a literatura de viagem no Brasil, este artigo delineia a construção da narradora-viajante de Outros cantos (2014), de Maria Valéria Rezende, abordando como a trama flerta e rompe com as características clássicas das narrativas de estrada, tendo como base, sobretudo, o estudo de Flora Sussekind (2006). No romance de Rezende a problemática do deslocamento e da rememoração são chaves de leitura importantes que permeiam toda a narrativa. Somado a isso, outro ponto fundamental tratado será a relação entre a viagem e a figuração do tempo nesse romance: a protagonista Maria é apresentada ao leitor, no plano do presente, dentro de um ônibus, rememorando uma experiência de quarenta anos atrás, durante uma viagem de retorno ao sertão nordestino, e no plano do passado, como uma espécie de forasteira recém-chegada a um desconhecido local, na mesma região.
\end{abstract}

Palavras-chave: Maria Valéria Rezende. Outros Cantos. Literatura de viagem. Literatura Contemporânea. Memória.

\begin{abstract}
Based on a brief description of how travel literature was configured in Brazil, this article outlines the construction of the narrator-traveler from Outros Cantos (2014), by Maria Valéria Rezende, addressing how the plot flirts and breaks with the classic characteristics of road narratives, based mainly on the study by Flora Sussekind (2006). In Rezende's novel, the problem of displacement and remembrance are important reading keys that permeate the entire narrative. In addition, another fundamental point will be the relationship between travel and the figuration of time in this novel: the protagonist Maria is presented to the reader, on the plane of the present, inside a bus, recalling an experience of forty years ago, return trip to the northeastern hinterland, and in the plane of the past, as a kind of outsider recently arrived to a unknown place, in the same region.
\end{abstract}

Keywords: Maria Valéria Rezende. Outros cantos. Travel literature. Contemporary Literature. Memory.

\footnotetext{
1 Mestranda do Programa de Pós-Graduação em Letras, linha de pesquisa Linguagem e Memória Cultural, da Universidade Federal de Ouro Preto (UFOP).
} 


\section{Percorrendo a literatura de viagem no Brasil}

Há uma intimidade entre a literatura de viagem e o memorialismo. Conforme o sujeito viaja e se coloca em deslocamento rumo a um destino desconhecido, o presente vai se reatualizando e ressignificando o passado, o que configura um processo mnemônico. Ao se deparar com os contornos de um novo local e cultura, o indivíduo, involuntariamente, acessará sua memória para compreender essa situação, comparando-a com experiências anteriores e expandindo sua bagagem espaço-cultural. O sociólogo francês Maurice Halbwachs (2003) é um notório estudioso da memória que cunhou a concepção de memória coletiva, na qual esse fenômeno, antes interpretado como estritamente biológico e individual, passa a ser compreendido a partir de seu caráter social. As lembranças que cada ser tem das experiências pessoais vivenciadas, estão diretamente relacionadas ao quadro social em que essa pessoa está inserida e ao acervo de recordações construídas e compartilhadas por esse grupo.

Na esteira de Halbwachs, o casal de estudiosos Aleida e Jan Assmann - professores na Universidade de Konstanz, na Alemanha - desdobrou o conceito de memória coletiva em duas distinções: a memória comunicativa e a memória cultural. A primeira se refere às memórias recentes

[...] produzidas na interação e na comunicação cotidiana e, por essa única razão, tem uma profundidade de tempo limitada, que normalmente alcança retrospectivamente não mais que 80 anos, o período de três gerações que interagem. (ASSMANN, 2008, 119)

Já a segunda seria a memória que se conecta ao passado remoto e "existe na forma de narrativas, canções, danças, rituais, máscaras e símbolos; (...) ela requer, para sua atualização, certas ocasiões durante as quais a comunidade se junta para uma celebração" (ASSMANN, 2008, 120), é considerada a memória ancestral, que se relaciona à origem dos povos.

Dessa forma, os pesquisadores alemães em questão propuseram uma nova forma de conceituar a recordação, que além de considerar o caráter social, agrega o viés cultural como parâmetro para as investigações mnemônicas. À vista disso, essa intrínseca relação com a memória constitui uma das bases fundamentais da ficção de estrada.

O romance Outros cantos têm como eixo essa relação, na qual a narradora-personagem viajante lembra - ao acessar a bagagem de sua vivência anterior - reatualizando o presente e 
ressignificando o passado. A princípio, se faz necessário percorrer o caminho traçado pelos relatos de estrada no Brasil, para adentrarmos à análise de como a obra literária em questão manifesta problemáticas próprias a essa tradição literária.

Flora Sussekind, em O Brasil não é longe daqui (2006), trata do surgimento do narrador como personagem-viajante na ficção brasileira. A partir da ideia de não-estar de todo, aborda os romances de aprendizado e a obsessão pela origem. O não-estar de todo compreende um estranhamento:

[...] a sensação de não pertencer, de ser outro, num álbum de família ou numa paisagem social mais ampla [...]. Nas ilhas misteriosas a que se chega de repente em certos livros, depois de longas viagens, não é como se, diante de uma paisagem mais que conhecida, o sujeito que as observasse se sentisse estrangeiro. (SÜSSEKIND, 2006, p. 13)

Esse sentimento é próprio do narrador viajante que, mesmo diante de uma paisagem anteriormente vista, expressa esse estranhamento ou por não pertencer àquele contexto ou por se deparar e atualizar a imagem desse ambiente. A autora considera essa sensação como uma espécie de topos clássico, utilizado na composição dos personagens, das narrativas de estrada.

O título do seu ensaio, O Brasil não é longe daqui, refere-se ao fragmento de uma antiga música alemã entoada como boas-vindas para os nativos de lá quando embarcavam rumo ao Brasil. Era utilizada como estímulo, uma espécie de propaganda para que os trabalhadores alemães, geralmente de classes menos favorecidas, imigrassem para nosso país. Posteriormente, esses dizeres tiveram o seu sentido transfigurado para um tom irônico, pois a vida boa e farta prometida em terras tupiniquins era uma fachada para as diversas explorações que a mão de obra estrangeira viria a sofrer. Essas interessantes questões históricas e hermenêuticas se relacionam com a temática da viagem de uma forma crítica, o que justifica a expressão que intitula sua obra. Além dessas possibilidades, há ainda uma terceira maneira de leitura desse dito, segundo a qual uma pessoa brasileira, que está no próprio país, afirmaria que “o Brasil não é longe daqui”, pois já não reconheceria mais a sua terra, o seu país. Estaria então acometida pela sensação de não-estar de todo em um lugar antes conhecido, e, que no momento o desconhece, o estranha. 
Mesmo acometido por esse inevitável estranhamento ${ }^{2}$, a cada cenário descortinado, o sujeito viajante ainda amplia suas perspectivas e atinge um certo nível de desenvolvimento pessoal. Segundo Süssekind,

[...] mesmo viagens medidas na colherinha de café, olhando-se de fora, dos fundos para os quadros de honra familiares e locais, aprendem-se, com ou sem anestesia, os próprios limites. [...] Diante de linhas duplas de vaivém [...] voltam-se, irônicas, para o próprio sujeito que as traçou. (SÜSSEKIND, 2006, p. 12)

Ou seja, independentemente de ser uma vontade consciente ou não, o narrador de estrada alarga seus horizontes e apreende coisas inéditas, desenvolvendo novos limites. O indivíduo, ao se lançar rumo ao desconhecido, durante esse processo de interpretação, mesmo que minimamente, agregará bagagem, conhecimento de mundo. Tanto esse aprendizado como a sensação de não-estar de todo estão interligados à obsessão pela origem.

É traçado um panorama para investigar a problemática da "origem" do narrador na literatura tupiniquim. Evidencia-se a busca exaustiva dos autores por uma identidade nacional pré-fabricada, estabelecendo a "literatura nacional em sua diferença, enquanto dotada de singularidade e de marcas inconfundíveis de brasilidade" (SÜSSEKIND, 2006, p. 16), o que revela a necessidade de afirmação da identidade brasileira se distinguindo do perfil europeu do colonizador português. O conjunto de escritores responsáveis por essa tarefa (de delinear e consolidar uma identidade nacional) é denominado como “eterno Adão", outra expressão chave utilizada ao longo dessa análise. A explicação para essa terminologia estaria relacionada à

[...] pressuposição de que as paisagens, gentes e coisas no mundo estariam como que vazias de sentido, à espera de quem as definisse. Olhar todopoderoso, com rede classificatória prévia e olhar armado que cravasse marcos, desse as cartas. (SÜSSEKIND, 2006, p. 269)

\footnotetext{
2 Karl Eric Schøllhammer, em Ficção brasileira contemporânea (2009), constata que essa sensação de estranhamento diante de um contexto se consolida como uma idiossincrasia da literatura contemporânea. Os autores do tempo presente observam a realidade que os cerca, distinguindo com clareza as diferenças em relação a outras épocas. Entretanto, por não concordarem com a fugacidade das relações pessoais e o empobrecimento da experiência desta conjuntura, criam um ângulo (que no caso seria a literatura) para expressar essa insatisfação. A protagonista do romance Outros cantos expressa esse descompasso temporal, uma vez que se encontra no presente da narrativa, mas por não se identificar e estar insatisfeita com os modos de viver configurados nessa época, decide partir, por meio da memória, para um contexto diferente, situado em uma temporalidade remota.
} 
Ou seja, o papel desses "eternos Adões" seria catalogar e exaltar as particularidades (convenientes) que distinguiriam o país (até então sem tradições). Para isso, foram instituídas características clássicas que aludissem à pátria brasileira como a descrição de cenários com abundante paisagem natural, exaltando a tropicalidade e ainda foram delineados heróis nacionais, entre outros. Qualquer obra literária que não se encaixasse exatamente nesse modelo seria desconsiderada.

A tentativa de fixar essa brasilidade só-natureza pré-fabricada, paisagem ilusória, se choca com o cenário real do país. O Brasil realmente tem uma natureza farta e fascinante, entretanto, como qualquer nação, possui problemas socioeconômicos e contradições diversas. Ou seja, essa imagem essencialmente natural, descontraída e sem problemas que procuravam firmar, por meio da literatura, figurava um ideal inalcançável diante das contradições modernas. Os autores e seus personagens, em meio a esse contraste, pareciam não-estar de todo nesse contexto, porém, de acordo com as convenções do século XIX, isso não deveria transparecer em seus textos.

Os relatos de viagem sobre o Brasil, a princípio, foram escritos, majoritariamente, por estrangeiros que viajavam pelo país e tomavam notas sobre suas impressões acerca do local. Esse olhar forasteiro sobre o país elevou a viagem a outro patamar, no qual adquiriu um caráter de experiência fundamental para os homens de Letras. Entretanto, a ótica estrangeira sobre outro país, outra cultura, geralmente é carregada de estereótipos e estigmas, e, assim, corre o risco de apresentar um perfil errôneo sobre o local, uma "imposição externa perante a cultura local”. Diante disso, ressalta-se a necessidade do olhar do viajante nativo para o seu próprio país, a importância de sua voz para a construção coerente da ficção de estrada que pudesse "registrar a paisagem" e "colher tradições" conhecidas e partilhadas (SÜSSEKIND, 2006, p. $55)$.

Ou seja, para evitar (e desfazer) possíveis impressões equivocadas, os autores brasileiros deveriam ocupar e se expressar, de seu lugar de fala, dedicando-se à construção de uma imagem mais próxima da realidade, por meio da literatura nacional. A partir disso surgem os narradoresviajantes dos anos 1830-40 no Brasil, dos quais trataremos mais adiante.

Süssekind traça um quadro evolutivo sobre a trajetória do narrador de ficção brasileiro, no qual é possível notar como ele se desenvolve e se transfigura nos diversos contextos histórico-sociais pelos quais o país transita. Em meados do século XIX, o cenário literário brasileiro ainda é um palco de experimentações, nas quais o narrador se encontra em trânsito, 
tanto no tocante à temática como em relação a sua composição (ainda instável). Esse período abarca os três principais narradores-viajantes - o cartógrafo, o historiador e o cronista. No recorte temporal dos anos 1830-40, a questão central estará na relação entre o narrador-viajante, as questões geográficas e o território.

A produção literária das décadas de 1830 e 1840 realiza uma espécie de mapeamento do território nacional. O narrador de viagem ora figura como cartógrafo, ora como paisagista, ora como retratista. $\mathrm{O}$ objetivo da prosa ficcional nesse contexto era delinear a identidade nacional, o que era feito por meio de tramas aventurescas previsíveis, geralmente guiadas por heróis viajantes que observavam os contornos da paisagem e da cultura brasileira com olhos de colecionador. $\mathrm{O}$ compromisso dos autores nesse período era introduzir traços de brasilidade em suas obras, mesmo que isso não funcionasse de maneira orgânica, muitas vezes se configurando de forma mecânica (e forçada), visivelmente proposital. Nessa época também são prefigurados o narrador-historiador e o narrador-cronista.

A obsessão pela configuração de mapas nacionais vem acompanhada da problemática das origens do país. Após a irrupção das questões geográficas, na segunda metade do século XIX, o narrador passa a empreender uma "escrita histórico-genésica e olhar armado pela busca de origens, gestações e fundações, marcar nas cartas e álbuns, nascentes, fontes, marcos inaugurais, raízes" (SÜSSEKIND, 2006, p. 190). Esse novo foco romanesco trata e atemporaliza os fatos históricos, baseando-se num misto de testemunhos alheios com "olhos do historiador".

José de Alencar com o seu romance histórico O guarani (1857) é um dos autores mais expressivos desse contexto. Seu projeto literário “tenta rastrear a 'gestação lenta' de um povo brasileiro" (SÜSSEKIND, 2006, p. 189), delineando e colocando em pauta a relação entre a figura do colonizador branco e do nativo colonizado, por meio da ótica do romantismo, como origem do brasileiro. Nesse romance são retratados vários embates entre os indígenas e os portugueses, o que apresenta aos leitores o passado histórico do Brasil, recriando o processo de colonização do país. O ponto central do enredo é o relacionamento amoroso entre Peri, índio pacífico e aspirante a herói da trama, e Ceci, filha de portugueses, legitimando a mestiçagem, gênese da raça brasileira. Em face disso, pela perspectiva da busca pelas origens, é possível uma leitura da homônima produção literária de Alencar que englobe tanto questões geográficas como históricas que constituem os pilares culturais nacionais. Além disso, em alguns textos anteriores pertencentes a época já é possível notar os contornos do cotidiano brasileiro. 
Entre as décadas de 1850 e 1860 é empreendido um mapeamento regional do país: a etiqueta nacional dos romances dos decênios anteriores, agora é substituída por uma etiqueta regional. O olhar do narrador sob a paisagem se torna contemplativo, em tramas compostas por muitos momentos de observação das banalidades do cotidiano. É nesse período que surge o gênero hoje conhecido como crônica "Não é apenas em historiador ou cartógrafo de mapas históricos-lendários regionais que se desdobra o narrador de ficção [...]. Em frequente conversa a dois com essas crônicas de costumes fixa-se a figura do narrador-cronista". (SÜSSEKIND, 2006, p. 233).

Esse tipo de texto, antes figurado como "crônicas de costumes", surge para mapear os modos de viver e as atividades do dia-a-dia dos brasileiros. O compromisso do narrador passa a ser observar as trivialidades particulares de cada região ou cidade. Trava-se "um jogo duplo necessário entre contemplação reflexiva da Natureza e observação miúda do cotidiano" (SÜSSEKIND, 2006, p. 222). O tom aventuroso deixa de ser obrigatório, os narradores de estrada agora poderiam figurar em viagens com trajetos curtos e tranquilos, que não envolvessem qualquer tensão. $\mathrm{O}$ olhar promovido por esse gênero, além de se atentar aos detalhes e às diversidades cotidianas, ainda focaliza figura peculiares e caricatas. Oposto a este tipo narrador e aos anteriores, o último, e um dos mais relevantes descritos no ensaio de Süssekind, é o complexo narrador machadiano.

Machado de Assis, com sua engenhosidade e ironia características, coloca em xeque todos os contornos que delineavam o narrador-viajante desde 1830 - a natureza, a origem e os costumes. O autor utiliza esse quadro, que fora configurado até os anos de 1960, como base introdutória para seus romances, nos quais o objetivo é desarmá-lo. Machado promove uma "quebra de expectativa aventuresca, o apequenamento propositado da intriga, a exibição mediana dos personagens" (SÜSSEKIND, 2006, p. 263), ao desconstruir o método de conceber esse tipo de narrativa, a lógica "sugestão-dúvida-revelação". Dessa forma o narrador-viajante machadiano incita o leitor a sair de sua zona de conforto, criando armadilhas e ambiguidades perante o narrado.

Em vez da contundente descrição e exaltação do ambiente natural brasileiro, o enredo machadiano se centra nas impressões de seu protagonista, "a viagem do narrador machadiano é ao redor de si mesmo, das dicções narrativas, dos casos diminutos e posições ideológicas do seu tempo" (SÜSSEKIND, 2006, p. 275). Na ficção do autor, o sentimento íntimo ocupa um 
lugar de destaque e as clássicas descrições empreendidas nos textos de estrada são colocadas em segundo plano.

No romance Outros cantos, tanto a composição da narradora-viajante como o desenrolar da história são configurados com métodos semelhantes, em alguns pontos, com o fazer ficcional de Machado de Assis, pois o deslocamento é tematizado para abordar a individualidade da narradora. Para abordar essa questão delinearemos o lugar que a prosa ficcional em questão ocupa no cenário da literatura de viagem brasileira.

\section{Percorrendo o Outros cantos}

“[...] é o próprio sujeito que emerge no seu percurso, o sentimento do mundo sintoniza-se ao autoconhecimento, o aprendizado é sempre também de si mesmo."

Flora Süssekind

Maria Valéria Rezende, em Outros cantos, empreende uma narrativa, na qual a protagonista, além da viagem física - a personagem imóvel, sentada na poltrona de um ônibus, em movimento, a caminho do sertão nordestino -, empreende uma viagem (auto) reflexiva, ao redor de si mesma, durante o passeio que faz pelo passado - por meio de suas rememorações. Apesar de descrever os contornos do local, delineando um quadro regional, a narrativa é centrada essencialmente nas impressões e aprendizados da protagonista. A narradorapersonagem viajante do romance flerta com a cartografia, a história e a crônica. Entretanto, a narradora rezendiana, assim como o machadiano, utiliza esse quadro clássico como base, para então desconstruí-lo no desenrolar da trama.

Diante dos olhos do espectador, partindo do cenário sertanejo, serão desdobradas paisagens geográficas, históricas e cotidianas. A primeira paisagem de uma narrativa de viagens clássica, em geral, é a cartográfica, na qual os aspectos geográficos e climáticos do espaço, onde a trama se desenrolará, são detalhadamente descritos. Nesse caso são delineados os contornos do sertão, nas duas temporalidades. Já a paisagem histórica - pano de fundo do romance -, retrata a traumática ditadura brasileira, que, mesmo se manifestando de forma mais contundente nas grandes cidades, repercute no sertão. No entanto, a paisagem que assume lugar de destaque na trama é a cotidiana, revelada durante o processo de aprendizado realizado por Maria. Segundo Sussekind "Todas essas paisagens são desdobradas da primeira, que se 
encontra em um processo de constante recomposição. A base de todas elas é uma só: o narradorviajante" (SÜSSEKIND, 2006, p. 157). Ou seja, todas as paisagens citadas são desenroladas a partir de uma imagem base, nesse caso o sertão nordestino primitivo, porém, o núcleo que articula todos esses elementos (as paisagens, os contextos e as temporalidades) durante esse processo é a protagonista-em-trânsito Maria.

O primeiro mote e um dos pilares de sustentação de uma narrativa de viagem é o seu teor aventuresco, conduzido, geralmente, por um personagem que se converte em uma espécie de herói. Na primeira descrição de Maria, a protagonista de Outros cantos, na introdução do romance, já é possível perceber como essa questão será configurada

\begin{abstract}
Eu fazia trinta anos no dia em que me meti pela primeira vez nesta aridez. Ainda não se havia espalhado por toda a terra a ilusão de poder-se fraudar o tempo e afastar indefinidamente o envelhecimento e a morte com as técnicas de cirurgias plásticas e calistenias, fórmulas químicas, discursos de autopersuasão, mantras, injeções, próteses, lágrimas e incensos. Então, só era possível fazê-lo tornando-nos heróis, mártires, mitos e símbolos. Apostava-se a vida no que acreditávamos ser maior que a nossa própria vida. Encher de sentido o tempo era, então, mais urgente pois tão passageiro, urgência de marcar o mundo com nossa existência, mesmo que arriscando-nos a torná-la ainda mais breve. Ultrapassar os trinta anos era atravessar o portal da juventude para a idade adulta. Era, então, o exato meio da vida. (REZENDE, 2016, p. 10)
\end{abstract}

A narradora-personagem traça o seu perfil, introduzindo a ideia de heroísmo como forma de "fraudar o tempo", permanecer, "tornando-nos heróis, mártires, mitos e símbolos", o que sugere os desafios que estão por vir. Ela reflete sobre a superficialidade do presente e o esvaziamento das experiências, que carecem mais feitos significativos. Ao enfatizar os seus trinta anos de idade como "o portal da juventude para a idade adulta" e "o exato meio da vida" transparece a vontade de realizar algo relevante que justifique a sua existência. A partir desse quadro pintado por Rezende, confirmam-se os contornos de uma narradora-viajante com pretensões a heroína, mito ou mártir, que objetiva eclodir uma revolução (ao se infiltrar) no sertão, em plena ditadura militar no país. Essa questão é o cerne da narrativa.

Maria assume esse papel de conquistadora, e, ao mesmo tempo, é conquistada pelo sertão. "O papel do conquistador costuma ser regra nesses livros de viagem, às vezes quebrase tal expectativa e são [...] as paisagens naturais, que parecem literalmente conquistar o seu visitante" (SÜSSEKIND, 2006, p. 13). A protagonista, no desenrolar da trama, conquista os 
nativos do local e durante esse processo também é arrebatada pelo modo de viver minimalista, a humildade e o carisma desse povo, que recebe bem a forasteira, o que faz ela logo se afeiçoar ao contexto por completo.

Durante esse processo de reconhecimento do local, Maria necessitava apreender aquela nova cultura, não só para conseguir sobreviver naquele ambiente extremo, mas para se camuflar, se tornar "um peixe dentro d'água". Para isso a protagonista passa a observar os "usos e costumes" da vila, tecendo suas impressões particulares sobre aquele cotidiano, o que se configura como um dos eixos do relato. Ao longo dessa ambientação a aprendizagem vai começando a tomar forma

Quando eu terminava a ingente faina de preparar a refeição e de lavar minha panela, meu prato e minha colher com areia e dois canecos d'água salobra, escondia-me no quarto - camarinha, ensinaram-se a dizer - onde à noite armava a minha rede de dormir, mas àquela hora quase inteiramente vazia de objetos, e esperava o momento do retorno ao trabalho. (REZENDE, 2016, p.22)

Nessa cena, nota-se o início do processo de aprendizado, no qual a narradora começa a compreender, desde o básico, sobre os modos de viver daquele local. As tarefas e atividades triviais assumem outras dimensões. Para lavar louças a água, o detergente e a esponja são substituídos por areia e água salobra. A nomenclatura quarto se converte em camarinha; a cama é trocada pela rede. Para Maria, personagem do meio urbano que migra para o rural, tudo é novo. Durante essa trajetória, a sertaneja que ensina Maria a (sobre) viver naquele cenário é Fátima, que guia e acompanha a protagonista do início ao fim de sua estadia no sertão remoto.

Encontrei ofício e família naquele canto escondido. Podia ficar, preenchida de estranha euforia, e, subitamente livre de uma espécie de cegueira frente ao desconhecido, comecei a ver cada um, cada coisa, cada movimento na sua unidade e seu sentido. Pelas mãos de Fátima cheguei ali de verdade. [...] ensinou-me todo o necessário para ao menos sobreviver. Não me ensinou tudo o que sabia, mas tudo o que podia ensinar. [...] Dela, paciência e persistência em salvar-me. De mim, orgulho e teimosia, dia após dia imperceptíveis avanços. (REZENDE, 2016, p.24)

Fátima revela os mistérios que o contexto particular do semiárido abriga para Maria. Esta se mostra uma aluna persistente nesse processo de adaptação, quase darwinista, em que é preciso se tornar mais forte para sobreviver. Ao declarar que se sentia "subitamente livre de uma espécie de cegueira frente ao desconhecido, comecei a ver cada um, cada coisa, cada 
movimento na sua unidade e seu sentido" percebe-se uma oposição de sentimentos que permeia todo o relato. Uma sensação permanente de estranhamento e não-pertencimento, mesmo em momentos nos quais a personagem já se encontra familiarizada com o local, fazendo parte do quadro. É empreendido um certo "dualismo narrativo", no qual as sensações de estar e nãoestar de todo no ambiente, muitas vezes se chocam, o que segundo Süssekind resultaria "ao seu protagonista transformações de fato significativas a partir das próprias experiências" (SÜSSEKIND, 2006, p. 248). Ou seja, essa questão paradoxal sobre o pertencimento que aflige os narradores-viajantes, pode vir a promover mudanças e evoluções consideráveis, ampliando a bagagem de aprendizado e desenvolvimento individual destes.

Além de flertar com o narrador-cronista, observando e assimilando aquela cultura, em um movimento recíproco de troca, a protagonista se transfigura em uma espécie de guia turístico. Em rodas de contação de história relata suas aventuras por outros países, outras paisagens, outras culturas. Durante essas ocasiões, os habitantes da vila podem ser considerados como espectadores sedentários que, em geral, se tornam reféns da imobilidade por força das circunstâncias que o local impõe. Esse narrador-guia proporciona aos sertanejos a oportunidade de empreender viagens sem sair do próprio lugar ao mergulharem em seus relatos. Conforme os laços entre a forasteira e os nativos vão se estreitando, eles começam a lhe devolver histórias e causos do local "eles me ofereciam suas histórias, duramente realistas ou risonhamente fabulosas, entremeadas com as minhas compondo novo xadrez de mundos diferentes, e eu aprendia o que era pertencer, de fato a um povo" (REZENDE, 2016, p. 32). Aleida Assmann, em Espaços da recordação (2011), desdobra a concepção “communautés affectives”, que versa sobre a relação de pertencimento a uma comunidade, cunhada por Maurice Halbwachs, afirmando que os "laços afetivos emprestam especial intensidade às memórias. Lembrar-se é uma realização de pertencimento, até uma obrigação social. Uma pessoa tem que lembrar para pertencer" (ASSMANN, 2011, p. 122). Nesse trecho de Outros cantos é possível perceber que a personagem Maria, por meio da contação de histórias, ultrapassa as fronteiras do estranhamento desse modo singular de (sobre) viver, aprofunda sua relação com os sertanejos e passa de fato a pertencer, afetivamente, ao sertão. No decorrer desse processo ocorre um alargamento da memória coletiva de Olho d'Água, que agora passa a incluir os saberes de Maria.

Essa miscelânia de histórias e causos, que compõe o romance de Rezende, delineia paisagens nacionais e estrangeiras. Segundo Sussekind "é a imagem-guia do "passeio" que 
permite a ele alinhavar, com sua cartografia miúda de cronista, tantos lugares, casos e épocas diversas por que se passa, ora rapidamente, ora com vagar nos menores detalhes" (SÜSSEKIND, 2006, p.230). Ou seja, é por meio de imagens - sobretudo as memorialísticas que a protagonista-viajante, resgata, configura, e, quiçá, eterniza suas vivências ao redor do mundo. Ao "rasgar um narrador e puxar dele paisagens diversas" o leitor poderia observá-lo como uma paisagem. Ao "rasgar" (abrir e examinar) a protagonista Maria, encontrar-se-ão cenários como: a Argélia, a França, a Índia, o Saara, além de São Paulo e o próprio povoado de Olho d'Água. E ela metamorfoseada em paisagem seria uma espécie de mosaico formado pelos fragmentos das culturas que atravessou. Entretanto, no presente, a paisagem que a representa de forma mais contundente é o sertão nordestino remoto e minimalista. Vivência tão emblemática que a faz retornar (e se aventurar) ao local quarenta anos mais tarde.

Esse caleidoscópio de paisagens representa a protagonista rezendiana, figura em mobilidade contínua, por territórios variados, durante toda a obra. Nota-se que esse perfil de narradora-em-trânsito começa a ser delineado desde a cena de abertura da narrativa

Olho de novo o perfil do homem sentado do outro lado do estreito corredor deste ônibus no qual, hoje, cruzo mais uma vez um sertão, qualquer sertão. Vi-o pela janela quando irrompeu e acenou à margem da estrada, vindo de nenhum caminho nenhuma habitação humana, emergindo do deserto, emaranhado compacto de garranchos e cactos. (REZENDE, 2016, p. 9)

A primeira ambientação apresentada ao leitor é o ônibus, no qual será empreendida uma travessia pelo sertão - o destino ainda não declarado é o lugarejo Olho d'Água. Avista-se, ao olhar pela janela, a segunda e principal ambientação da trama, o sertão nordestino, paisagem introduzida com uma breve e clássica descrição do local, um "deserto, emaranhado compacto de garranchos e cactos". Essa composição anuncia uma narrativa de estrada, na qual, desde o primeiro momento, a protagonista está em deslocamento e o leitor é convertido em seu companheiro de viagem, para o qual confidenciará suas experiências, entre aventuras e desventuras, como numa espécie de diário de bordo.

A narradora, antes de se aventurar nos confins do semiárido nordestino, confessa ter realizado pesquisas prévias sobre o local

Quando decidi [...] entranhar-me no sertão [...] pretendi tudo saber de antemão, o já acontecido e o ainda por vir, lendo tudo o que as literaturas me ofereciam. Mergulhar mais fundo na terra e abrir os olhos sob a superfície, porém, permitia ver uma vida miúda, insuspeitável, que não chegava à tona 
nos livros. A cada passo um espanto, obrigando-me a perguntar tudo a todos. (REZENDE, 2016, p. 18)

Por meio de leituras literárias e de materiais diversos, Maria demonstra ter embarcado relativamente preparada para enfrentar a missão de (sobre) viver naquele ambiente. Além da questão estratégica que essa espécie de laboratório pré-viagem teria, é externalizado o medo diante do famigerado sertão nordestino. Quando a protagonista fala que "a cada passo um espanto", isso se relaciona, primeiramente, ao estranhamento do desconhecido, mas também pode ser lido como a expressão de uma real sensação de medo diante do temido contexto. $\mathrm{Na}$ primeira descrição do vilarejo apresentada ao leitor, as casas do local são personificadas e expressam essa sensação de receio

$[\ldots]$ olha vagamente $[\ldots]$ as poucas casas brancas, de janelas e portas fechadas, agarradas umas às outras, mortas de medo do imenso e árido espaço à sua volta. Entre elas, a rua larga de areia branca e salgada, mais salina que sertão, esparsas algarobas quase transparentes, insistindo em dizerem-se verdes naquele cenário branco e cinzento. (REZENDE, 2016, p. 11)

Os contornos do povoado reproduzidos pela protagonista revelam o seu olhar perante a paisagem agreste. Assim como as casas, janelas e portas, Maria também tem "medo do imenso e árido espaço à sua volta”. Entretanto, se surpreende com o verde das algarobas, que resistem saudáveis, em meio ao clima extremo. Nesse primeiro momento esboça-se um clima misterioso, que gera expectativas sobre o que ainda está por vir na narrativa.

Nas cenas iniciais, após esse olhar apreensivo, Maria trava um processo de reconhecimento desse contexto a partir da comparação com experiências anteriores. "Custavame caminhar pela areia solta daquela rua branca, como tinha me custado avançar pelas dunas do Saara" (REZENDE, 2016, p. 19). O simples ato de caminhar, naquele contexto ganha novo sentido, já que diferente do asfalto dos contextos urbanos aos quais a protagonista estava acostumada, no contexto rural do sertão o solo é de areia. Apesar de trabalhoso, percorrer esse tipo de cenário não é novidade para ela, essa sensação aciona memórias de suas andanças pelo deserto do Saara. Essa espécie de analogia, via aproximações mnemônicas, é natural diante de uma nova conjuntura, o que provoca o reconhecimento (a interpretação) desta.

Outra passagem emblemática sobre esse processo é quando a guia sertaneja da narradora apresenta a ela uma receita essencial para o povo nordestino, o cuscuz 
Agora, cuidar do cuscuz... Se você não aprender, vai comer o quê?" O cuscuz, Fátima repetiu várias vezes, não havia dúvida, a mesma das vésperas de festa de minha família paulista, a mesma que me surpreendera no oásis argelino, na voz daquela outra, Fatuma, ensinando-me a umedecer e acariciar a sêmola até que se cobrisse o fundo de um amplo al-gidar com uma grossa camada branca, leve e granulada, que o vapor transformaria no kuskus nosso de todo dia. Como hoje, uma palavra, uma imagem, um gesto bastavam para fazer ressurgir outros, outras lembranças, ao sabor dos acasos como vários rolos de um filme projetados fora de ordem, ajudando-me a reconhecer o desconhecido. (REZENDE, 2016, p. 26; 27)

Nessa cena acontece um diálogo entre a cultura nordestina, a paulistana e a argelina, travado por um elo alimentar, que seria o cuscuz. Essa preparação faz parte da memória afetiva da Maria - remete à cozinha típica de São Paulo, em suas reuniões familiares, e à cozinha típica da Argélia, aprendida com a nativa Fatuma. O modo de comer, somado ao de caminhar, entre outros atos cotidianos, contribui para que a cada dia a narradora-viajante passe a se reconhecer um pouco mais naquele quadro.

Além das lembranças do contato travado com outras culturas, como já exposto, a personagem-viajante, em movimentos de vaivém, percorre o presente e os diferentes passados, durante o romance, o que indica um trabalho sistemático com as temporalidades, no qual a presença de um de terceiro locutor vem à tona, "O tempo". Por esse viés, transfigurado em personagem, ele pode ser incluído no núcleo principal da trama, ao lado de Maria e Fátima. Ou seja, essa temporalidade não linear configura o tempo como uma peça fundamental para essa narrativa, na qual passa-se do contexto do pós-golpe de 1964 ao nordeste do século XXI, de um parágrafo para outro.

No cenário descortinado na frente de casa, podia-se ver o silêncio sólido do fim de tarde de um domingo num mundo sem nada, sem ninguém, mundo sem criador parecia. Só eu estava lá, mergulhada na ausência, incrustada e imobilizada na quentura espessa, como um fóssil na rocha. [...] Alguém, no assento logo atrás do meu, liga um rádio e me obriga a ouvir fragmentos de sermões evangélicos, de funks, de anúncios comerciais, e finalmente se resolve por um programa de canções melosas, a duas vozes, a mais alta uma terça acima da mais grave, pontuadas por gritos de locutor de rodeio, "Segura peão!". (REZENDE, 2016, p. 12;13)

Dois espaços e tempos se alternam nesse fragmento. No primeiro momento, Maria, que chegara há pouco na vila, não havia se deparado com nenhum habitante e por isso se mostra hesitante. Já no segundo momento, Maria, dentro do ônibus, relata a poluição sonora que a perturba naquele ambiente. Essas duas situações se dão de um parágrafo para outro no romance. 
Diante disso, é possível perceber um flerte com o narrador-historiador, já que esses movimentos ziguezagueantes (trocas de tempo histórico) permeiam toda a narrativa.

Nas histórias de memórias, a imersão do narrador nesse processo temporal é quase inevitável. Maria Valéria Rezende bem como Machado de Assis não blinda sua protagonistaviajante contra uma possível corrosão de seu ponto de mira. Na temporalidade remota, a imagem ingênua do sertão, que antes deslumbrara Maria, próximo ao clímax da narrativa, parece ruir. A protagonista se depara com o lado sombrio desse ambiente ao presenciar uma cena de violência doméstica, comum naquele contexto rural,

Nem pensei, num impulso dei um tranco na porta que se abriu facilmente e vi, à contraluz [...] as silhuetas da mulher que tentava proteger-se com os braços levantados diante da cara, e o do homem que empunhava um grosso relho e a segurava pelos cabelos, ambos paralisados pela surpresa de minha entrada a berrar "Para, para, seu covarde!" [...] Só depois de um grande caneco d'água adoçada com rapadura fui capaz de contar, entre soluços, a cena toda. "Ixe! E você foi se meter nisso, menina? É doida? Nunca ouviu dizer que: em briga de marido e mulher, ninguém mete a colher?" quis protestar, mas Fátima insistiu, "É costume, ninguém morre disso não. $\mathrm{O}$ meu homem nunca me bateu, é doce como um mel, mas a gente não tem nada haver com o que se passa na casa dos outros. Aprenda". Calei-me, e ali fiquei, escorada na parede, um nó doloroso apertando minha cabeça e meu coração, a cortina idealista que me tapava os olhos e só me permitia ver a dor infligida pela exploração do Dono e a inclemência do sol, mais a beleza dos gestos e saberes do povo, rasgando-se mais um pouco e revelando que tudo era muito mais misturado e complicado que eu pensava. (REZENDE, 2016, p. 124;125)

Maria se espanta, diante dessa cena, e se dá conta de como os valores extremamente machistas ainda estão arraigados naquela cultura. No meio urbano, o que há algumas décadas foi configurado como um crime, ainda é tratado com naturalidade pelos sertanejos, tanto que a própria Fátima afirma ser um costume. A partir disso, somam-se à exploração do Dono, cenas de autoflagelação e a demora pela verba - patriarcalismo, tradições extremadas, coronelismo e abandono político-econômico -, Maria passa a enxergar os aspectos negativos daquela comunidade. Ou seja, no decorrer do tempo, as primeiras impressões são substituídas por um olhar mais analítico para as raízes estruturais daquela localidade.

Na contemporaneidade da trama, também é possível perceber uma corrosão, que nesse caso estaria ligada à imagem minimalista do sertão nordestino remoto, que durante a viagem de retorno para o mesmo local, vai sendo desconstruída e atualizada. Entretanto, a nova paisagem que vai sendo descortinada não agrada a protagonista. Agora, traços urbanos passam a fazer parte de um novo sertão globalizado - o autismo digital, o consumismo desenfreado, a poluição 
sonora, entre outros, o que se difere da imagem orgânica que cativara Maria quarenta anos atrás. Ou seja, a memória preserva uma imagem intocada dos locais, que, no entanto, é ilusória. É quase impossível que um contexto permaneça o mesmo após quase meio século de história. Essas mudanças, de antemão, já são esperadas pela protagonista, mas na prática é penoso se conformar com esses novos contornos. Ao se deparar com essas mudanças, para a narradora, o sertão atual passa a se configurar como uma espécie de ruína do sertão primitivo.

\section{Considerações finais}

Em face do exposto, cabe um retorno à expressão “o Brasil não é longe daqui”, justificada por Sussekind como "uma observação expressa por alguém que já não reconhece nele a paisagem anunciada" (SÜSSEKIND, 2006, p. 21), o que se relaciona à ideia do nãoestar de todo. Essa questão pode ser percebida quando a narradora, no presente, compartilha da mesma sensação, pois não reconhece o sertão nordestino de suas memórias. Em muitos momentos, se refere a sua versão remota como "outro sertão", "chão já fora do tempo" e "meu velho sertão". Já na versão atual, ela o trata como "um sertão", "chão de hoje" e "qualquer sertão", o que deixa clara a sua relação afetiva com o antigo sertão e o seu estranhamento com sua nova variante. Ou seja, o sertão de seu imaginário mnemônico já não existe mais e a sua versão contemporânea está “em desacordo com o seu mapa do sonho". Diante dessa situação, a narradora poderia proferir uma frase semelhante à que intitula o ensaio, o sertão não é longe daqui. A revolução de baixo para cima pode ser considerada o foco da narradora do romance Outros cantos, nas duas temporalidades. Já que, tanto a militante infiltrada na primeira temporalidade como a professora e ex-moradora do sertão objetivam conscientizar a população sertaneja para que possam combater o abandono político-econômico da região e lutar por seus direitos, a fim de melhores condições de vida. A princípio foi exposto esse caráter heroico da protagonista, contudo, no desenrolar da trama, acontece uma corrosão do objetivo proposto, e, consequentemente, "desarme prosaico e irrefutável à heroização aventuresca do viajante" (SÜSSEKIND, 2006, p. 261).

Esse desarme acontece a partir do momento no qual a sugestão inicial (uma revolução partindo do sertão nordestino) se perde no desenrolar da narrativa (a demora da verba atrasa o andamento dessa empreitada). E, quando, finalmente, é possível dar início ao processo, Maria é descoberta e vai embora às pressas do povoado. Esse desfecho (no tempo pregresso) tem uma 
forte carga de tensão e comoção, porém, é menos heroico do que se supunha. Há uma quebra de expectativas, por meio da qual o caráter heroico sofre uma inversão e agora pode ser atribuído aos moradores do vilarejo, que alertam a protagonista e traçam um plano de fuga para que ela consiga deixar o local a salvo.

Tanto no passado como no presente o final da trama permanece em aberto - no primeiro ela foge em um caminhão de carga; no segundo ela chega ao destino, mas não é apresentada ao leitor nenhuma cena de sua palestra. Ambos os desfechos não cumprem com o heroísmo sugerido na abertura do romance e se desfaz "parte do encantamento que costuma produzir as narrativas maravilhadas e misteriosas de viagens e da glorificação, por tabela, de seus protagonistas" (REZENDE, 2016, p. 262). Maria termina o romance do mesmo jeito que começou: "As esperanças levadas por mim naquela primeira viagem eram muito maiores e mais curtas que as de agora, cujo sopro me fez embarcar nesse ônibus" (REZENDE, 2016, p. 12), esperançosa de empreender mudanças. Talvez o fato de não ter cumprindo sua promessa, na temporalidade anterior, alcançando seu propósito, a tenha afligido por todos esses anos e a impulsionado a empreender esse retorno em busca de uma segunda chance, mesmo que tardia, de mudar a vida daquela gente e marcar o mundo com sua existência.

Maria Valéria Rezende não constrói uma protagonista apenas com a função de “observadora de costumes e quadros históricos". Maria é uma narradora-personagem viajante profunda e perspicaz, que, além de retratar a viagem e o sertão, a partir de seu ponto de vista subjetivo, expõe os problemas que assolam cada contexto e se mostra uma pessoa engajada que almeja contribuir, nas duas temporalidades, suscitando consciência crítica aos sertanejos, o que coloca essas questões socioeconômicas e comportamentais em pauta e suscita reflexão nos leitores.

\section{Referências}

ASSMANN, J. “Communicative and cultural memory”. In: ERLL, A; NÜNNING, A. (Ed.). Cultural memory studies: an international and interdisciplinary handbook. Berlin; New York: De Gruyter, 2008. p. 109-118.

ASSMANN, A. Espaços da recordação: formas e transformações da memória cultural. Tradução de Paulo Soethe (coord.). Campinas, SP: Editora da Unicamp, 2011. 
HALBWACHS, M. A memória coletiva. Tradução de Beatriz Sidou. $2^{a}$ ed. SãoPaulo: Ed. Centauro, 2013.

REZENDE, M. V. Outros cantos. Rio de Janeiro: Alfaguara, 2016.

SCHØLLHAMMER, Karl Eric. Ficção brasileira contemporânea. Rio de Janeiro: Civilização Brasileira, 2009.

SÜSSEKIND, F. O Brasil não é longe daqui: o narrador, a viagem. São Paulo: Companhia das Letras, 2006.

Artigo recebido em: 19.09.2020

Artigo aceito para publicar em: 09.11.2020 